\title{
Uji Daya Hambat Ekstrak Buah Belimbing Manis (Averrhoa carambola) terhadap Pertumbuhan Bakteri Streptococcus pneumoniae secara In Vitro
}

\author{
Rita Risandi', Aziz Djamal ${ }^{2}$, Asterina $^{3}$
}

\begin{abstract}
Abstrak
Buah belimbing manis (Averrhoa carambola) merupakan salah satu tanaman Indonesia yang diyakini memiliki khasiat obat. Salah satu manfaat yang dapat diambil dari sari buah belimbing manis (Averrhoa carambola) adalah dapat mengobati radang tenggorokan. Radang tenggorokan merupakan salah satu infeksi yang disebabkan oleh bakteri Streptococcus pneumoniae. Tujuan penelitian ini adalah menentukan daya hambat ekstrak buah belimbing manis (Averrhoa carambola) terhadap pertumbuhan bakteri Streptococcus pneumoniae secara in vitro. Metode studi ini ialah eksperimental dengan desain postest only control group design yang dilakukan di Laboratorium Biota Sumatera Universitas Andalas dan Laboratorium Mikrobiologi Fakultas Kedokteran Universitas Andalas dari Agustus sampai Oktober 2014. Hasil penelitian menunjukkan bahwa ekstrak buah belimbing manis (Averrhoa carambola) dengan konsentrasi yaitu 5\%,10\%, 15\% dan 20\% tidak memiliki daya hambat terhadap pertumbuhan bakteri Streptococcus pneumoniae. Hal ini terbukti karena tidak terbentuk zona hambat pada agar darah dan tidak terdapat pengaruh lama kontak ekstrak buah belimbing manis (Averrhoa carambola) terhadap pertumbuhan bakteri Streptococcus pneumoniae secara in vitro. Ekstrak buah belimbing manis tidak memiliki efek antibakteri terhadap pertumbuhan bakteri Streptococcus pneumoniae.
\end{abstract}

Kata kunci: ekstrak buah belimbing manis, Streptococcus pneumoniae, daya hambat

\section{Abstract}

Star fruit (Averrhoa carambola) is a Indonesian plant that is believed to have medicinal properties. One of the benefits that can be drawn from the juice of star fruit (Averrhoa carambola) is the ability to treat strep throat. Strep throat is a bacterial infection caused by Streptococcus pneumoniae. The objective of this study was to determine the inhibitory extract of star fruit (Averrhoa carambola) on the growth of the bacterium Streptococcus pneumoniae in vitro. This was an experimental research with design posttest only control group design that conducted in the Laboratory of Biota Sumatra Andalas University and Laboratory of Microbiology, Faculty of Medicine, Andalas University from August to October by 2014. The results showed that the extract of star fruit (Averrhoa carambola) has no inhibitory effect on the growth of the bacterium Streptococcus pneumoniae with various concentrations of 5\%, 10\%, $15 \%$, and $20 \%$. No inhibition zones formed on blood agar and there is no effect of contact time extracts of star fruit (carambola Averhhoa) on the growth of the bacterium Streptococcus pneumoniae in vitro. Star fruit extracts do not have antibacterial effects against Streptococcus pneumoniae bacteria growth.

Keywords: extract of star fruit, Streptococcus pneumoniae, Inhibition

Affiliasi penulis: 1. Prodi Profesi Dokter FK UNAND (Fakultas Kedokteran Universitas Andalas Padang), 2. Bagian Mikrobiologi FK UNAND, 3. Bagian Kimia FK UNAND.
Korespondensi :Rita Risandi, Email: risandi.rita@yahoo.com Telp: 085211568565 


\section{PENDAHULUAN}

Indonesia memiliki beraneka ragam kekayaan tumbuhan. Ada 3000 spesies tumbuhan yang sekitar 1200 spesies dapat dimanfaatkan sebagai obat. Menurut Undang - Undang Nomor 23 tahun 1992 tentang kesehatan adalah bahan atau ramuan bahan yang berupa tumbuhan, hewan, bahan mineral, sediaan sarian (galenik) atau campurannya, yang secara turun - temurun telah digunakan untuk pengobatan berdasarkan pengalaman. Obat ini lebih menguntungkan karena efek sampingnya yang lebih kecil, mudah di dapat dan tidak memerlukan biaya yang besar. ${ }^{1}$

Sejalan dengan pemanfaatan tumbuhan obat ini, penelitian terhadap tanaman sebagai sumber antibiotika alamipun semakin berkembang. Hal ini berdasarkan karena semakin banyaknya kuman yang menjadi resisten terhadap antibiotika sehingga tidak dapat lagi membunuh atau menghambat pertumbuhan kuman yang menjadi penyebab penyakit. ${ }^{2}$

Salah satu tanaman Indonesia yang diyakini memiliki khasiat obat adalah buah belimbing manis (Averrhoa carambola). Buah belimbing manis (Averrhoa carambola) dapat digunakan untuk mencegah dan mengatasi sakit tenggorokan, obat batuk, menurunkan tekanan darah (antihipertensi), sebagai antioksidan, menurunkan kolesterol, melancarkan pencernaan, menurunkan panas (demam), mencegah sariawan, mengobati jerawat, menghilangkan rasa mual dan muntah, melancarkan air seni, mengeluarkan dahak dan untuk meningkatkan daya tahan tubuh. ${ }^{3-6}$

Streptococcus pneumoniae merupakan penghuni normal pada saluran pernapasan bagian atas manusia. Bakteri Streptococcus pneumoniae dapat menyebabkan pneumonia, sinusitis, otitis, bronkitis, bakterimia, meningitis dan proses infeksi lainnya. Streptococcus pneumoniae dapat menimbulkan infeksi melalui kemampuannya berkembang biak dalam jaringan dan menyebar luas sehingga menimbulkan serangan mendadak seperti demam, menggigil dan nyeri pleura yang nyata. ${ }^{7,8}$

Streptococcus pneumoniae sensitif terhadap banyak antimikroba. Obat pilihan dari penyakit ini adalah penisilin. Pengobatan yang dini biasanya menghasilkan penyembuhan cepat, dan peran respon antibodi tampaknya banyak berkurang. Akhir - akhir ini timbul resistensi terhadap beberapa obat, seperti tetrasiklin, eritromisin, dan linkomisin. Peningkatan resistensi terhadap penisilin juga terlihat pada Streptococcus pneumoniae yang diisolasi dari New Guinea. $^{7,9}$

Banyaknya kuman yang menjadi resisten terhadap antibiotika tertentu termasuk kuman Streptococcus pneumoniae, mengakibatkan penelitian terhadap tanaman sebagai sumber antibiotika alamipun semakin berkembang. Salah satunya adalah penelitian mengenai kandungan buah belimbing manis (Averrhoa carambola) yang telah dilakukan oleh Sukadana (2009), menunjukkan adanya golongan flavonoid sebesar 0,2027\%. Flavonoid dapat menghambat sintesis asam nukleat, menghambat fungsi membran sitoplasma, menghambat metabolisme energi pada sel bakteri, mendenaturasi protein sel yang menghambat pertumbuhan atau menyebabkan kematian sel sehingga di katakan memiliki sifat sebagai antibakteri. ${ }^{10}$

Hal di atas didukung juga oleh Muliani (2012), yang menunjukkan bahwa ekstrak buah belimbing mempunyai aktivitas hambatan terhadap Streptococcus mutans pada kadar $25 \%, 50 \%$, dan $70 \% .{ }^{11}$ Menurut Widyowidagdo dan Sitanggang tahun 2002, bahwa ekstrak buah belimbing mempunyai aktivitas hambatan terhadap Streptococcus pyogens, Eschericia Coli, dan Staphylococcus aereus pada kadar $20 \%$, 40\% dan $80 \%$. Ekstrak kental buah belimbing manis diketahui positif mengandung senyawa golongan flavonoid, alkaloid, saponin, dan tanin. ${ }^{12}$

Berdasarkan hal di atas, perlu dilakukan penelitian uji daya hambat ekstrak buah belimbing manis (Averrhoa carambola) terhadap pertumbuhan kuman Streptococcus pneumoniae secara in vitro.

\section{METODE}

Penelitian telah dilakukan di Laboraturium Mikrobiologi Fakultas Kedokteran Universitas Andalas dari Agustus sampai Oktober 2014. Studi ini bersifat 
eksperimental dengan desain postest only control group design. Variabel bebas adalah ekstrak buah belimbing manis (Averrhoa carambola) dengan berbagai konsentrasi yaitu $5 \%, 10 \%, 15 \%$, dan $20 \%$ dan variabel terpengaruh adalah bakteri Streptococcus pneumoniae. Data hasil penelitian diolah dengan uji Anova satu arah dengan derajat kepercayaan 95\% $(=0,05)$, bila didapat perbedaan nyata antar perlakuan maka akan dilanjutkan dengan uji Kruskal Wallis.

\section{HASIL}

Tabel 1. Daya hambat ekstrak buah belimbing manis (Averrhoa carambola) terhadap pertumbuhan bakteri Streptococcus pneumoniae secara in vitro

\begin{tabular}{cccccccc}
\hline & \multicolumn{1}{c}{ Diameter Bebas Kuman (mm) } & Diameter \\
\cline { 2 - 6 } & I & II & III & IV & V & VI & $\begin{array}{c}\text { Bebas } \\
\text { kuman rerata }\end{array}$ \\
\hline $5 \%$ & 0 & 0 & 0 & 0 & 0 & 0 & 0 \\
$10 \%$ & 0 & 0 & 0 & 0 & 0 & 0 & 0 \\
$15 \%$ & 0 & 0 & 0 & 0 & 0 & 0 & 0 \\
$20 \%$ & 0 & 0 & 0 & 0 & 0 & 0 & 0 \\
\hline
\end{tabular}

Tabel 1 memperlihatkan hasil bahwa ekstrak buah belimbing manis (Averrhoa carambola) dalam berbagai konsentrasi tidak menghasilkan daerah bebas kuman pada pertumbuhan bakteri Streptococcus pneumoniae secara in vitro, berarti tidak ada daya hambat ekstrak buah belimbing manis (Averrhoa carambola) terhadap pertumbuhan bakteri Streptococcus pneumoniae di dalam penelitian ini.

Tabel 2. Diameter daerah bebas pertumbuhan Streptococcus pneumoniae pada kontrol

\begin{tabular}{|c|c|c|c|c|c|c|c|}
\hline \multirow[b]{2}{*}{$\%$} & \multicolumn{6}{|c|}{ Diameter bebas Kuman (mm) } & \multirow{2}{*}{$\begin{array}{c}\text { Diamete } \\
\text { bebas } \\
\text { kuman } \\
\text { rerata }\end{array}$} \\
\hline & $I$ & II & III & IV & $\mathbf{V}$ & VI & \\
\hline $\begin{array}{l}\text { Kontrol } \\
\text { Positif }\end{array}$ & 18,2 & 18,3 & 18,6 & 17,2 & 18,8 & 19,1 & 18,36 \\
\hline $\begin{array}{l}\text { Kontrol } \\
\text { Negatif }\end{array}$ & 0 & 0 & 0 & 0 & 0 & 0 & 0 \\
\hline
\end{tabular}

Pada Tabel 2 didapatkan hasil bahwa ampisilin yang digunakan sebagai kontrol positif memberikan daya hambat yang baik terhadap pertumbuhan Streptococcus pneumoniae secara in vitro dan didapatkan hasil bahwa dimethyl sulfoxide yang digunakan sebagai kontrol negatif tidak menghasilkan daerah bebas kuman pada pertumbuhan bakteri Streptococcus pneumoniae secara in vitro, berarti tidak ada daya hambat dimethyl sulfoxide terhadap pertumbuhan bakteri Streptococcus pneumoniae.

Tabel 3. Pengaruh lama kontak dari ekstrak buah belimbing manis (Averrhoa carambola) yang memiliki daya hambat maksimal terhadap pertumbuhan bakteri Streptococcus pneumoniae

\begin{tabular}{cc}
\hline Lama kontak & Pertumbuhan Kuman \\
\hline Seketika & - \\
5 Menit & - \\
10 Menit & - \\
15 Menit & - \\
20 Menit & - \\
25 Menit & - \\
30 Menit & -
\end{tabular}

Tabel 3. menunjukkan bahwa lama kontak dari ekstrak buah belimbing manis (Averrhoa carambola) yang memiliki daya hambat maksimal tidak berpengaruh terhadap pertumbuhan bakteri Streptococcus pneumoniae, hal ini terlihat dari bakteri tidak tumbuh pada daerah agar darah.

\section{PEMBAHASAN}

Hasil yang didapat menunjukkan bahwa tidak ditemukan zona hambat ekstrak buah belimbing manis (Averrhoa carambola) terhadap pertumbuhan bakteri Streptococcus pneumoniae secara in vitro serta tidak ada pengaruh lama kontak ekstrak buah belimbing manis (Averrhoa carambola) terhadap pertumbuhan bakteri Streptococcus pneumoniae seperti yang terlihat di Tabel 1 dan 3 . Hal ini kemungkinan dipengaruhi oleh beberapa hal seperti metode yang digunakan, jenis varietas belimbing manis (Averrhoa carambola), tipe bakteri, struktur antigen dan virulensi, dan faktor lingkungan tempat tumbuh belimbing manis (Averrhoa carambola).

Perbedaan metode sangat berpengaruh terhadap perbedaan hasil penelitian. Pada penelitian yang dilakukan oleh Muliani di tahun 2012, mengenai 
Daya Antibakteri Ekstrak Buah Belimbing Manis (Averrhoa carambola) terhadap pertumbuhan bakteri Streptococcus mutans secara in vitro menggunakan metode dilusi. Metode dilusi berfungsi untuk melihat konsentrasi hambat minimum (KHM) dengan teknik yang lebih kompleks. ${ }^{11}$ Pada penelitian ini metode yang digunakan adalah metode sederhana yaitu metode difusi dengan menggunakan cakram. Metode ini digunakan karena keterbatasan alat dan waktu.

Perbedaan jenis varietas kemungkinan juga berpengaruh terhadap daya hambat ekstrak buah belimbing manis (Averrhoa carambola) terhadap Streptococcus pneumoniae. Pada penelitian ini jenis varietas yang digunakan adalah varietas Dewi. Penelitian yang dilakukan oleh Kathleen pada tahun 2011 didapatkan bahwa belimbing manis (Averrhoa carambola) varietas Madu memiliki daya hambat terhadap pertumbuhan bakteri Streptococcus mutans.

Walaupun belum ada literatur yang menjelaskan mengenai perbedaan kandungan dan senyawa antibakteri antara setiap varietas, namun kemungkinan ada perbedaan kandungan senyawa pada setiap varietas. $^{13}$

Tipe bakteri yang digunakan juga berpengaruh ada atau tidaknya daya hambat ekstrak buah belimbing manis (Averrhoa carambola) yang digunakan dalam penelitian ini. Perbedaan tipe disebabkan oleh perbedaan struktur. Streptococcus pneumoniae memiliki polisakarida simpai secara imunologik masing-masing berbeda satu sama lain kurang lebih 80 tipe. Bagian somatik Streptococcus pneumoniae mengandung protein $\mathrm{M}$ yang khas dan suatu karbohidrat spesifik. Karbohidrat dapat dipresipitasikan oleh protein reaktif-C, suatu zat yang di temukan dalam serum penderita tertentu. Perbedaan tipe bakteri menyebabkan perbedaan enzim atau zat lainnya yang dihasilkan oleh bakteri dan menyebabkan perbedaan dinding sel masingmasing tipe bakteri. ${ }^{6}$

Pada penelitian ini Streptococcus pneumoniae yang digunakan diambil dari sampel pasien dengan tipe bakteri yang tidak diketahui. Bakteri memiliki reseptor antibakteri yang akan berikatan dengan zat antibakteri yang dikandung ekstrak buah belimbing manis (Averrhoa carambola), sehingga antibakteri yang diberikan bisa bekerja sesuai dengan yang diinginkan. Bisa saja Streptococcus pneumoniae yang digunakan dalam penelitian ini tidak memiliki reseptor yang dimaksud.

Alasan pengambilan bakteri Streptococcus pneumoniae dari sampel pasien, karena bakteri yang ada di Laboratorium Mikrobiologi Fakultas Kedokteran Unand hanya yang berasal dari pasien. Bakteri yang berasal dari pasien mempunyai keefektifan yang berbeda terhadap antibiotik. Kemungkinan dalam penelitian ini bakteri yang digunakan resisten terhadap zat antibakteri yang ada pada sampel.

Buah belimbing manis (Averrhoa carambola) yang digunakan dalam penelitian ini berasal dari tanaman yang tumbuh secara liar, sehingga faktor lingkungan seperti sifat biologis dan kimia tanah, suhu, kelembapan, pupuk, dan lain-lain, tidak terkontrol secara baik. Faktor tidak terkontrol tersebut juga akan berpengaruh terhadap jumlah zat antibakteri yang ada pada sampel. Jika jumlah zat antibakteri rendah atau tidak ada maka tidak akan timbul daya hambat terhadap pertumbuhan bakteri. Flavonoid memiliki daya hambat pertumbuhan bakteri gram positif jika kadar nya 500 ppm dan gram negatif 100 ppm, jika kurang kandungannya, maka flavonoid tidak dapat menghambat pertumbuhan bakteri. ${ }^{10}$

Lama kontak ekstrak buah belimbing manis (Averrhoa carambola) juga tidak berpengaruh terhadap pertumbuhan bakteri Streptococcus pneumoniae. Konsentrasi yang digunakan adalah konsentrasi yang memiliki daya hambat maksimal, tetapi karena tidak ada daya hambat ekstrak buah belimbing manis (Averhhoa carambola) dalam berbagai konsentrasi, jadi konsentrasi digunakan adalah konsentrasi tertinggi yaitu konsentrasi $20 \%$. Didapatkan hasil penelitian adalah ekstrak buah belimbing manis (Averrhoa carambola) tidak memiliki daya antibakteri yang kuat sehingga tidak dapat menghambat pertumbuhan bakteri dalam waktu yang telah ditentukan.

Berdasarkan hasil penelitian ini, maka dapat dinyatakan bahwa hipotesis penelitian tidak terbukti, karena tidak terdapat daya hambat ekstrak buah 
belimbing manis (Averrhoa carambola) pada konsentrasi $5 \%, 10 \%, 15 \%$, dan $20 \%$ terhadap pertumbuhan bakteri Streptococcus pneumoniae dan tidak terdapat pengaruh lama kontak ekstrak buah belimbing manis (Averrhoa carambola) terhadap pertumbuhan bakteri Streptococcus pneumoniae pada waktu seketika, 5 menit, 10 menit, 15 menit, 15 menit, 20 menit, 25 menit dan 30 menit secara in vitro.

\section{KESIMPULAN}

Tidak ditemukan daya hambat ekstrak buah belimbing manis (Averrhoa carambola) terhadap pertumbuhan bakteri Streptococcus pneumoniae in vitro pada konsentrasi 5\%, 10\%, 15\% dan 10\%.

Tidak terdapat pengaruh lama waktu kontak ekstrak buah belimbing manis (Averrhoa carambola) terhadap pertumbuhan bakteri Streptococcus pneumoniae secara in vitro pada waktu seketika, 5 menit, 10 menit, 15 menit, 20 menit, 25 menit, dan 30 menit.

\section{UCAPAN TERIMA KASIH}

Terima kasih kepada semua pihak atas bimbingan, bantuan dan motivasi dalam penelitian ini.

\section{DAFTAR PUSTAKA}

1. Tampubolon. OT "tumbuhan obat". Jakarta: Brata Karya; 1998.

2. Santoso HB. Pengembangan obat tradisional merupakan upaya untuk meningkatkan peranan obat tradisional dalam upaya pelayanan kesehatan. Jakarta: Buletin POM 1998.

3. Budiana NS. Buah ajaib tumpas penyakit. Jakarta: Penebar Swadaya. 2013
4. Cahyono B. Cara sukses berkebun belimbing manis. Jakarta: Pustaka Mina; 2010.

5. Lamb AJ, Cushnie T. Antimicrobial activity of flavonoids. International Journal of Antimicrobial Agents. 2005;343-56.

6. Payal G, Pankti K, Manodeep C, Jagadish K. Phytochemical and pharmacological profile of averrhoa carambola linn. International Research Journal of Pharmacy. 2012;3(1):88-92.

7. Jawetz E, Meknick, Adelherg. Mikrobiologi kedokteran (terjemahan). Jakarta:EGC. 2004; 21833.

8. Greenwood D, Richard CB, Slack, John F, Peutherer. Medical microbiology. China:Churchill Livingstone;2002.

9. Burrows W. Textbook of microbiology. Mexico: Nueva Editorial Interamericana. 1908.

10. Sukadana IM. Senyawa antibakteri golongan flavonoid dari buah belimbing manis (Averrhoa carambola Linn) (skripsi). Bali: Universitas Udaya; 2009.

11. Muliani MS. Daya antibakteri ekstrak buah belimbing manis (Averrhoa carambola) terhadap Streptococcus Mutans in vitro (skripsi). Yogyakarta: Fakultas Kedokteran Gigi Universitas Muhammadiyah Yogyakarta; 2012.

12. Wiryowidagdo S, Sitanggang M. Tanaman obat untuk penyakit jantung, darah tinggi, dan kolesterol. Jakarta: Agromedia Pustaka; 2002; 145.

13. Kathleen J. Ekstrak Averrhoa carambola (belimbing manis) dan Piper betle (sirih hijau) terhadap pertumbuhan Streptococcus mutans (skripsi). Surabaya: Universitas Airlangga; 2011. 